\title{
Penerapan Model Nht Untuk Meningkatkan Aktivitas Dan Hasil Belajar Bola Voli Pada Siswa Kelas X Teknik Kecantikan Smk Negeri 2 Singaraja
}

\author{
I Ketut Catur Suradnya ${ }^{1}$ I Putu Darmayasa, S.Pd, M.For \\ 1 Jurusan Pendidikan Jasmani Kesehatan dan Rekreasi Universitas \\ Pendidikan Ganesha \\ Singaraja, Bali \\ email: (catursuradnya44@gmail.com, ${ }_{1}^{1}$ putudarmayasa39@gmail.com)@undiksha.ac.id
}

\begin{abstract}
Abstrak
Penelitian ini bertujuan untuk meningkatkan aktivitas dan hasil belajar bola voli melalui penerapan model NHT pada siswa kelas X Tata Kecantikan SMK Negeri 2 Singaraja. Penelitian ini tergolong PTK yang dilaksanakan dalam dua siklus. Subyek penelitian ini adalah siswa kelas X Tata Kecantikan yang berjumlah 36 orang. Data dianalisis menggunakan analisis statistik deskriptif. Hasil analisis data observasi awal aktivitas belajar bola voli secara klasikal sebesar 33,33 (cukup aktif), setelah diberi tindakan pada siklus I meningkat menjadi 61,11 (aktif) dan meningkat menjadi 100 (aktif) pada siklus II. Analisis data ketuntasan hasil belajar pada observasi awal sebesar $27,78 \%$, setelah diberi tindakan pada siklus I meningkat menjadi 38,89\% dan meningkat menjadi $100 \%$ pada siklus II.Berdasarkan hasil analisis data dan pembahasan, simpulan penelitian ini adalah aktivitas dan hasil belajar bola voli meningkat melalui Implementasi Model Pembelajaran Kooperatif tipe NHT pada siswa kelas X Tata Kecantikan SMK Negeri 2 Singaraja dan hasil belajar bola voli.
\end{abstract}

Kata-kata kunci : NHT, aktivitas, hasil belajar, bola voli.

\begin{abstract}
This study aims to increase the activity and learning outcomes of volleyball through the application of NHT type cooperative learning models in class X Tata beauty SMK Negeri 2 Singaraja $2018 / 2019$ school year. This study is classified as classroom action research conducted in two cycles, with the form of teacher as researcher. The subjects of this study were class X students of beauty which amounted to 36 people. Data were analyzed using descriptive statistical analysis. The results of the analysis of the initial observation data of volleyball learning activities classically amounted to 33.33 (quite active), after being given action in the first cycle increased to 61.11 (active) and increased to 100 (active) in the second cycle. Analysis of completeness of learning outcomes data on preliminary observations of $27.78 \%$, after being given action in the first cycle increased to $38.89 \%$ and increased to $100 \%$ in the second cycle. Based on the results of data analysis and discussion, the conclusion of this study is the activity and learning outcomes of volleyball increased through the Implementation of NHT type Cooperative Learning Model in class X Tata beauty SMK Negeri 2 Singaraja academic year 2018/2019. It is recommended that the physical education teacher can implement the NHT type cooperative learning model in the learning process because it can increase the activity and learning outcomes of volleyball.
\end{abstract}

Key words: NHT, activity, learning outcomes, volleyball. 


\section{Pendahuluan}

Pendidikan adalah suatu usaha sadar untuk menyiapkan peserta didik melalui kegiatan bimbingan, pengajaran dan latihan yang menjadi tolak ukur dan memiliki peranan di masa yang akan datang dan berlangsung seumur hidup dengan tujuan meningkatkan kualitas kehidupan pribadi dan masyarakat. "Pembelajaran efektif terjadi apabila para pebelajar secara aktif terlibat dalam tugas-tugas yang bermakna dan aktif terlibat dalam berinteraksi dengan isi pelajaran" (Santyasa \& Sukadi, 2007:30). Pendidikan jasmani, olahraga dan kesehatan merupakan media untuk mendorong pengembangan keterampilan motorik, kemampuan fisik, pengetahuan dan penalaran, penghayatan nilai-nilai serta pembaiasaan pola hidup yang sehat bermuara untuk merangsang pertumbuhan dan perkembangan yang seimbang (Depdiknas, 200: 1).

Berdasarkan hasil observasi awal yang peneliti lakukan di SMK Negeri 2 Singaraja pada hari, Selasa, 21 Agustus 2018 yang bertempat dilapangan bola voli Gor Bhuna Patra pada pukul 05.30 Wita, terkait materi passing atas dan bawah permainan bola voli yang berjumlah 36 orang, dilihat dari aktivitas belajar siswa yang mencakup kegiatan-kegiatan seperti visual, lisan, mendengarkan, metrik, mental dan emosional pada materi teknik dasar passing atas dan bawah bola voli, siswa yang aktif 5 orang $(13,16 \%)$ dan siswa yang tidak aktif 33 orang $(86,84 \%)$, sedangkan siswa yang berada pada kategori sangat aktif tidak ada $0 \%$, siswa dalam kategori aktif 5 orang $(13,16 \%)$, siswa dalam kategori cukup aktif sebanyak 26 orang $(68,42 \%)$ siswa dalam kategori kurang aktif sebanyak 7 orang $(18,42 \%)$ dan kategori sangat kurang aktif tidak ada (0\%). Data aktivitas belajar teknik dasar passing bola voli diperoleh secara klasikal yaitu 75. Sedangkan untuk hasil belajar teknik dasar bola voli passing atas dan bawah berpedoman pada kriteria ketuntasan minimal (KKM) nilai mata pelajaran PJOK SMK Negeri 2 Singaraja 75 yang meliputi tiga aspek yaitu: sikap, pengetahuan dan keterampilan. Maka diperoleh hasil tes keterampilan passing atas dan passing bawah siswa yang tuntas 13 orang $(36,11 \%)$ dan siswa yang tidak tuntas 23 orang $(63,89 \%)$, sedangkan siswa yang berada pada kategori sangat baik tidak ada $(0 \%)$, siswa pada kategori baik 13 orang $(36,11 \%)$, siswa pada kategori cukup baik sebanyak 9 orang (25\%), siswa pada kategori kurang baik sebanyak 14 orang $(38,88 \%)$, dan tidak ada siswa pada kategori sangat kurang baik (0). Data keterampilan belajar teknik dasar passing bola voli diperoleh secara klasikal yaitu 75 katagori tidak tuntas.

Berdasarkan permasalahan yang telah diuraikan, diketahui aktivitas dan hasil belajar teknik dasar passing bola voli masih rendah. Adapun permasalahan yang dialami siswa dalam pembelajaran tersebut dari segi aktivitas belajar siswa adalah (1) dilihat dari segi lisan siswa belum berani mengemukakan pendapat dalam proses pembelajaran, (2) dari segi metrik siswa belum mampu melakukan gerakan-gerakan sesuai dengan materi pelajaran dengan baik dan benar, (3) dari segi mental siswa belum bisa memecahkan masalah atau kesulitan-kesulitan yang ditemui dalam proses pembelajaran, (4) dari segi emosional siswa kurang bersemangat dalam melakukan teknik dasar passing bola voli. Sedangkan untuk hasil belajar permasalahan yang muncul terdapat pada aspek kognitif, afektif dan psikomotor yang kurang.

\section{Metode Penelitian}

Penelitian ini adalah penelitian tindakan kelas (PTK) karena bertujuan memperbaiki kualitas pembelajaran yang bermuara pada peningkatan kualitas kinerja guru dan peningkatan aktivitas serta hasil belajar siswa. "Menurut Arikunto, dkk (2006: 3), menyatakan bahwa, "PTK merupakan suatu pencermatan terhadap kegiatan belajar sebuah tindakan, yang sengaja dimunculkan dan terjadi dalam sebuah kelas secara bersama." Oja (dalam Kanca, 2010: 115) adanya empat bentuk PTK, yaitu: 1) guru sebagai peneliti, 2) penelitian tindakan kolaboratif, 3) simultas-terintegrasi, 4) administrasi sosial eksperimental.

Setting penelitian adalah menjelaskan dimana penelitian dilakukan, kapan, dalam kondisi apa, dan lamanya tindakan secara rinci sesuai dengan banyak siklus yang diprediksi. Penelitian ini telah dilaksanakan pada siswa kelas X TK3 SMK Negeri 2 Singaraja yang berjumlah 36 orang putra 0 orang dan 36 putri tahun pelajaran 2018/2019 dalam 
pembelajaran passing bola voli pada pukul 05.30 wita sampai 07.00 wita yang dilaksanakan pada hari selasa dan jumat bertempat di lapangan voli Gor Bhuana Patra mulai yang dilaksanakan pada tanggal 14 agustus, 18 agustus, 28 agustus dan 01 september 2018.

Penelitian ini dilaksanakan 2 (dua) siklus, di mana masing- masing siklus terdiri dari 2 (dua) kali pertemuan. Pada pertemuan pertama diberikan pembelajaran secara penuh, terkait materi yang diberikan, sedangkan pada pertemuan kedua diberikan pengulangan untuk memantapkan penguasaan materi yang sebelumnya telah diberikan pada pertemuan pertama, dan sekaligus pengambilan data hasil belajar teknik dasar passing bola voli dengan dievaluator oleh 2 orang yaitu: 2 orang guru Penjasorkes di SMK Negeri 2 Singaraja. Pada siklus I materi yang diberikan adalah pembelajaran teknik dasar passing bola voli (passing atas dan passing bawah), sedangkan pada siklus II materi yang diberikan materi pemantapan dari pembelajaran teknik dasar passing bola voli (passing atas dan passing bawah) jika terjadi ketidak tuntasan di siklus I.

Adapun tujuan penelitian yang ingin dicapai adalah: Untuk meningkatkan aktivitas belajar dan hasil belajar teknik dasar bola voli passing atas dan passing bawah melalui penerapan model pembelajaran kooperatif tipe NHT pada siswa kelas TK3 SMK Negeri 2 Singaraja tahun pelajaran 2018/2019.

\section{Hasil Penelitian dan Pembahasan}

Data observasi awal aktivitas belajar teknik dasar bola voli passing atas dan passing bawah tahun pelajaran 2018/2019, siswa dalam katagori sangat aktif tidak ada $0 \%$, siswa dalam kategori aktif 5 orang (13,16\%), siswa dalam kategori cukup aktif sebanyak 26 orang $(68,42 \%)$ siswa dalam kategori kurang aktif sebanyak 7 orang $(18,42 \%)$ dan kategori sangat kurang aktif tidak ada (0\%).

Tabel 4.1 Data Aktivitas Belajar Bola Voli Passing Atas dan Pasing Bawah

\begin{tabular}{ccccc}
\hline No & Kategori & Jumlah & Persentase & $\begin{array}{c}\text { Jumlah siswa yang } \\
\text { aktif }\end{array}$ \\
\hline 1 & Sangat Aktif & 0 siswa & 0 & $33,33 \%$ \\
2 & Aktif & 12 siswa & 33,33 & siswa aktif \\
3 & Cukup Aktif & 15 siswa & 41,67 & $66,67 \%$ \\
4 & Kurang Aktif & 9 siswa & 25 & siswa belum aktif \\
5 & Sangat Kurang Aktif & 0 siswa & 0 & \\
\hline \multicolumn{2}{l}{ Jumlah } & $\mathbf{3 6}$ siswa & $\mathbf{1 0 0}$ & $\mathbf{1 0 0} \%$ \\
\hline
\end{tabular}

Secara rekapitulasi penilaian hasil belajar teknik dasar bola voli passing atas dan passing bawah siswa dalam katagori sangat aktif 0 siswa (0\%), aktif sebanyak 12 siswa (33,33\%), cukup aktif sebanyak 15 siswa (41,67\%), kurang aktif 9 siswa (25\%), dan sangat kurang aktif 0 siswa $(0 \%)$. Dari analisis data pada penelitian tindakan kelas observasi awal hasil belajar teknik dasar bola voli passing atas dan passing bawah pada siswa kelas X TK3 SMK Negeri 2 Singaraja.

Table 4.5 Ketuntasan Hasil Belajar Bola Voli Passing Atas dan Passing Bawah Pada Observasi Awal

\begin{tabular}{ccccc}
\hline No & Kategori & Jumlah & Persentase & $\begin{array}{c}\text { Jumlah siswa yang } \\
\text { aktif }\end{array}$ \\
\hline 1 & Sangat Baik & 0 siswa & 0 & $27,78 \%$ \\
2 & Baik & 10 siswa & 27,78 & siswa aktif \\
3 & Cukup Baik & 11 siswa & 30,56 & $72,22 \%$ \\
\hline
\end{tabular}




\begin{tabular}{ccccc}
\hline 4 & Kurang Baik & 15 siswa & 41,67 & siswa belum aktif \\
5 & Sangat Kurang Baik & 0 siswa & 0 & \\
& Jumlah & 36 siswa & 100 & $100 \%$ \\
\hline
\end{tabular}

Berdasarkan hasil analisis data pada siklus I, maka didapatkan hasil yang dikelompokkan berdasarkan kriteria penggolongan aktivitas belajar teknik dasar bola voli passing atas dan passing bawah, siswa dalam katagori sangat baik 0 siswa (0\%), baik sebanyak 10 siswa $(27,78 \%)$, cukup sebanyak 11 siswa $(30,56 \%)$, dan kurang 15 siswa $(41,67 \%)$. Dengan memperhatikan data aktivitas belajar pada siklus I dalam hal ini aktivitas belajar teknik dasar bola voli passing atas dan passing bawah.

Tabel 4.6 Data Aktivitas Belajar Bola Voli Passing Atas dan Passing Bawah Pada Siklus I

\begin{tabular}{|c|c|c|c|c|c|c|c|}
\hline \multicolumn{2}{|c|}{ kap $^{\mathrm{Si}}$} & \multicolumn{2}{|c|}{ Pengetahuan } & \multicolumn{2}{|c|}{ Ketarampilan } & \multirow{2}{*}{$\begin{array}{c}\text { Jumlah } \\
\text { Siswa }\end{array}$} & \multirow{2}{*}{ Ket } \\
\hline Skor & Predikat & Skor & Huruf & $\begin{array}{l}\text { Capain } \\
\text { Optimum }\end{array}$ & Huruf & & \\
\hline $90-100$ & $\begin{array}{c}\text { SB } \\
\text { (Sangat Baik) }\end{array}$ & $90-100$ & $A$ & $90-100$ & $A$ & $\begin{array}{c}5 \\
\text { Siswa }\end{array}$ & $\begin{array}{l}13,89 \% \\
\text { Tuntas }\end{array}$ \\
\hline $78-89$ & $\begin{array}{c}\text { B } \\
\text { (Baik) }\end{array}$ & $78-89$ & $B$ & $78-89$ & B & $\begin{array}{l}31 \\
\text { Siswa }\end{array}$ & $\begin{array}{c}86,11 \% \\
\text { Tuntas }\end{array}$ \\
\hline $75-77$ & $\begin{array}{c}\text { C } \\
\text { (Cukup) }\end{array}$ & $75-77$ & C & $75-77$ & $\mathrm{C}$ & $\begin{array}{c}5 \\
\text { Siswa }\end{array}$ & $\begin{array}{l}13,89 \% \\
\text { Tidak Tuntas }\end{array}$ \\
\hline$<75$ & $\begin{array}{c}\text { K } \\
\text { (Kurang) }\end{array}$ & $<75$ & D & $<75$ & $D$ & $\begin{array}{c}0 \\
\text { Siswa }\end{array}$ & $\begin{array}{c}0 \% \\
\text { Tidak Tuntas }\end{array}$ \\
\hline
\end{tabular}

\section{Pembahasan}

Mengacu pada data observasi awal, dapat disampaikan bahwa aktivitas dan hasil belajar bola voli passing atas dan passing bawah masih rendah. aktivitas belajar siswa pada saat observasi awal terhadap pembelajaran pendidikan jasmani olahraga dan kesehatan khususnya pada materi bola voli passing atas dan passing bawah secara klasikal berada pada kategori cukup aktif yaitu dari jumlah siswa 36 orang, yang tergolong sangat aktif 0 siswa (0\%), aktif sebanyak 12 siswa (33,33\%), cukup aktif sebanyak 15 siswa $(41,67 \%)$, kurang aktif 9 siswa (25\%), dan sangat kurang aktif 0 siswa $(0 \%)$.

Sedangkan rata-rata hasil belajar bola voli passing atas dan passing bawah yaitu siswa dalam katagori sangat baik 0 siswa (0\%), baik sebanyak 10 siswa $(27,78 \%)$, cukup sebanyak 11 siswa $(30,56 \%)$, dan kurang 15 siswa $(41,67 \%)$. Hal ini disebabkan model pembelajaran yang digunakan oleh guru kurang bervariasi yang sifatnya monoton dan menyebabkan siswa jenuh dalam menerima materi yang disampaikan oleh guru, maka dari itu peneliti akan memecahkan masalah tersebut dengan melakukan penelitian menggunakan model pembelajaran yang lain. Model pembelajaran yang digunakan peneliti dalam memecahkan masalah tersebut adalah menggunakan model pembelajaran kooperatif tipe Numbered Head Together (NHT). Peningkatan aktivitas belajar teknik dasar bola voli passing atas dan passing bawah pada siswa kelas X TK 3 SMK Negeri 2 Singaraja dari observasi awal, siklus I dan siklus II. 
Tabel 4.16 Persentase Peningkatan Aktivitas Belajar Per-Siklus Materi Bola Voli Passing Atas dan Passing Bawah

\begin{tabular}{|c|c|c|c|c|c|c|}
\hline \multirow[b]{2}{*}{ No } & \multirow[b]{2}{*}{ Tahapan } & \multirow[b]{2}{*}{$\begin{array}{c}\text { Persentas } \\
\text { e Aktivitas } \\
\text { Belajar }\end{array}$} & \multirow[b]{2}{*}{$\begin{array}{c}\text { Keaktifan } \\
\text { Siswa }\end{array}$} & \multicolumn{3}{|c|}{ Peningkatan Aktivitas Belajar } \\
\hline & & & & $\begin{array}{c}\text { Observasi } \\
\text { Awal ke } \\
\text { Siklus I }\end{array}$ & $\begin{array}{l}\text { Siklus I } \\
\text { ke Siklus } \\
\text { II }\end{array}$ & $\begin{array}{c}\text { Observasi } \\
\text { Awal ke } \\
\text { Siklus II }\end{array}$ \\
\hline 1. & $\begin{array}{c}\text { Observasi } \\
\text { Awal }\end{array}$ & 33,33 & $\begin{array}{l}\text { Cukup } \\
\text { Aktif }\end{array}$ & & & \\
\hline 2. & Siklus I & 61,11 & Aktif & 21,18 & 38,89 & 66.67 \\
\hline 3. & Siklus II & 100 & Aktif & & & \\
\hline
\end{tabular}

Dari data tabel diatas dapat disampaikan bahwa terjadi peningkatan sebesar $27,78 \%$ dari observasi awal ke siklus I, terjadi peningkatan sebesar38,89\% dari siklus I ke siklus II dan terjadi peningkatan $66,67 \%$ dari observasi awal ke silkus II. Peningkatan hasil belajar teknik dasar bola voli passing atas dan passing bawah pada kelas siswa X TK3 SMK Negeri 2 Singaraja Tahun Pelajaran 2018/2019 dari siklus I dan siklus II.

Tabel 4.17 Persentase Peningkatan Hasil Belajar Per-Siklus Materi Bola Voli Passing Atas dan Passing Bawah

\begin{tabular}{|c|c|c|c|c|c|c|}
\hline \multirow[b]{2}{*}{ No } & \multirow[b]{2}{*}{ Tahapan } & \multirow[b]{2}{*}{$\begin{array}{c}\text { Persentas } \\
\text { e Hasil } \\
\text { Belajar }\end{array}$} & \multirow[b]{2}{*}{$\begin{array}{c}\text { Ketuntasa } \\
\text { n Siswa }\end{array}$} & \multicolumn{3}{|c|}{ Peningkatan Hasil Belajar } \\
\hline & & & & $\begin{array}{c}\text { Observa } \\
\text { si Awal } \\
\text { ke Siklus } \\
\text { | }\end{array}$ & $\begin{array}{c}\text { Siklus I } \\
\text { ke } \\
\text { Siklus II }\end{array}$ & $\begin{array}{c}\text { Observasi } \\
\text { Awal ke } \\
\text { Siklus II }\end{array}$ \\
\hline 1. & $\begin{array}{c}\text { Observasi } \\
\text { Awal }\end{array}$ & $27,78 \%$ & $\begin{array}{l}\text { Belum } \\
\text { Tuntas }\end{array}$ & & & \\
\hline 2. & Siklus I & $86,11 \%$ & $\begin{array}{l}\text { Sudah } \\
\text { Tuntas }\end{array}$ & $58,33 \%$ & & $72,22 \%$ \\
\hline 3. & Siklus II & $100 \%$ & $\begin{array}{l}\text { Sudah } \\
\text { Tuntas }\end{array}$ & & $13,89 \%$ & \\
\hline
\end{tabular}

Dari data tabel diatas dapat disampaikan bahwa terjadi peningkatan sebesar $58,33 \%$ dari observasi awal ke siklus I, terjadi peningkatan sebesar $13,89 \%$ dari siklus I ke siklus II dan terjadi peningkatan $72,22 \%$ dari observasi awal ke silkus II. Berdasarkan data penelitian di atas maka dapat yakini bahwa implementasi model pembelajaran kooperatif tipe NHT dapat meningkatkan aktivitas dan hasil belajar teknik dasar passing bola voli pada siswa kelas X TK3 SMK Negeri 2 Singaraja tahun pelajaran 2018/2019. Keberhasilan dalam penelitian ini sesuai juga dengan yang dikemukakan oleh Hamalik (2008: 171) yang menyatakan bahwa pembelajaran yang efektif adalah pembelajaran yang menyediakan kesempatan belajar sendiri dan beraktivitas sendiri kepada siswa. Siswa belajar dan beraktivitas sendiri untuk memperoleh pengalaman, pengetahuan, pemahaman dan tingkah laku lainnya serta mengembangkan ketrampilan yang bermakna. Sehingga dapat disimpulkan bahwa kegiatan atau aktivitas belajar siswa merupakan dasar untuk mencapai hasil belajar yang optimal. 
Penelitian yang sudah dilaksanakan ini tidaklah selalu berjalan dengan lancar sesuai dengan yang diharapkan dan yang sudah direncanakan, karena ada kendala- kendala yang dihadapi peneliti dalam menjalankan penelitian ini. Adapun kendala-kendala yang dihadapi adalah respon siswa untuk memahami materi tergolong lambat; 2) Lapangan olahraga terlalu banyak yang menggunakan sehingga siswa tidak leluasa untuk bergerak. Dari kendala-kendala yang dihadapi tersebut maka yang dilakukan peneliti untuk memecahkannya sehingga penelitian yang dilakukan dapat berjalan dengan lancar diantaranya adalah: 1) menjelaskan kembali secara berulang-ulang materi yang belum dimengerti agar siswa lebih memahami materi yang dipelajari; 2) menyiapkan lapangan terlebih dahulu agar tidak didahului oleh kelas lain.

\section{Simpulan}

Berdasarkan analisis dan pembahasan di atas dapat di tarik kesimpulan sebagai beriku: Aktivitas belajar bola voli passing atas dan passing bawahmeningkat melalui penerapan model pembelajaran kooperatif tipe Numbered Head Together (NHT) pada siswa kelas X TK3 SMK Negeri 2 Singaraja tahun pelajaran 2018/2019. Hal ini dapat dilihat dari data peningkatan yang terjadi pada aktivitas belajar bola voli passing atas dan passing bawahsecara keseluruhan. Hasil belajar bola voli passing atas dan passing bawahmeningkat melalui penerapan model pembelajaran kooperatif tipe Numbered Head Together (NHT) pada siswa kelas X TK3 SMK Negeri 2 Singaraja tahun pelajaran 2018/2019. Hal ini dapa tdilihat dari data peningkatan yang terjadi pada hasil belajar bola voli passing atas dan passing bawah secara keseluruhan.

\section{Daftar Pustaka}

Agussuprijono. 2009. Cooperatife Learning. Yogyakarta: Pustaka Belajar.

Ari Pandini, Kadek. 2012. Aktivitas dan hasil belajar tolak peluru meningkat melalui model pembelajaran kooperatif tipe NHT pada siswa kelas VII SMP Negeri 1 Sawan tahun pelajaran 2012/2013. Singaraja: Undiksha.

Arikunto, Suharsimi. 2010. Penelitian Tindakan Kelas. Jakarta: PT. BumiAksara.

BSNP. 2006. Standar Isi untuk Satuan Pendidikan Dasar dan Mengah. Jakarta: kemendiknas.

Daniel Paul Baker. 2013. NHT adalah alat belajar yang lebih efektif bagi siswa yang berkinerja lemah dan anak laki-laki di Kimia dan terbukti efektif untuk mayorita ssiswa lain, dibandingkan dengan belajar kimia secara individual. Louisiana State University.

Dimyatidan Mudjiono. 2006. Belajar dan Pembelajaran. Jakarta: Departemen Pendidikan dan Kebudayaan dan Rineka Cipta.

Husdarta, H.J.S. 2009.Manajemen PendidikanJasmani. Bandung: Alfabeta.

Ibrahim.2000. Model pembelajarankooperatif.jak arta: University Prees.

Kanca, I Nyoman. 2010. Metodologi Penelitian Pengajaran Penjasorkes. Singaraja: Universitas Pendidikan Ganesha.

Koyan, I Wayan. 2009. Statistik Dasar dan Lanjut (Teknik Analisis Data Kuantitatif). Singaraja: Universitas Pendidikan Ganesha.

Lanang Agung Parwata, I Gusti. 2010. Buku Ajar Teoridan Praktek Atletik. $\quad$ Singaraja: Universitas Pendidikan Ganesha.

Made Aryananda Wijaya Kusuma, I Dewa. 2011. Implementasi Model Pembelajaran Kooperatif Tipe Numbered Head Together (NHT) Untuk Meningkatkan 
Aktivitas dan Hasil Belajar Teknik Dasar Passing Sepak Bola Pada Siswa Kelas X3 SMA Negeri 1 Tampak siring Tahun Pelajaran 2011/2012. Singaraja:Undiksha.

Mulyasa. 2006. Kurikulum Tingkat Satuan Pendidikan. Bandung: PT Remaja Rosdakarya. Nana, Sudjana. 2006. Penilaian Hasil Proses Belajar Mengajar. Bandung: PT Remaja Rusdakarya.

Nurhadi. 2004. Pembelajaran Kontekstual dan Penerapannya dalam KBK. Malang: Universitas Negeri Malang.

Nurhasandan Sukardjo. 1992. Evaluasi Pengajaran Pendidikan Jasmani dan Kesehatan. Jakarta: Depdikbud.

Nurhasan. 2001. Tes Pengukuran Dalam Pendidikan Jasmani Prinsip-Prinsip Dan Penerapannya. Jakarta: Direktorat jendral olahraga.

Nurkancana, Wayan dan Sunartana. 1992. Evaluasi Hasil Belajar. Surabaya: Usaha Nasional.

Permendiknas. Nomor 104 tahun 2014. Penilaian Hasil Belajar Oleh Pendidik Pada Pendidikan Dasar dan pendidikan menengah. 2014. Jakarta: Kemendiknas.

Santyasa, I Wayan. 2007. Model-Model Pembelajaran Inovatif. Universitas Pendidikan Ganesha.

Slavin, E Robert. 2010. Pembelajaran Kooperatif: Teori, risetdan Praktek. Bandung : Nusa Media.

Sriundy Mahardika, I Made. 2010. Pengantar Evaluasi Pengajaran. Surabaya: UNESA University Press.

Suherman, Adang. 2001. Asesmen Belajar Dalam Pendidikan Jasmani. Jakarta Pusat: Direktorat Jendral Olahraga.

Suherman. 2001. Atletik. Bandung: Alfabeta

Suprana Jaya Andika, Made. 2013. Aktivitas dan hasil belajar lompa tjauh gaya jongkok dan gaya menggantung meningkat melalui model pembelajaran kooperatif tipe NHT pada siswa kelas XI IA 1 SMA Negeri 1 Kuta tahun pelajaran 2012/2013. Singaraja:Undiksha.

Suprijono, Agus. 2009. Cooperative Learning TeoridanAplikasi. Yogyakarta: PustakaBelajar.

Suroto.2007. Buku Model Pembelajaran Penjasorkes Inovatif Untuk Pendidikan Dasar. Surabaya: Departemen Pendidikan Nasional BALITBANG- PUSLITJAKNOV.

Trianto. 2007. Model-Model Pembelajaran Inovatif Berorientasi Konstruktivistik. Jakarta: Prestasi Pustaka Publisher. 